\title{
MELIMEX, an experimental heavy metal pollution study: Vertical mixing in a large limno-corral ${ }^{1}$ )
}

\author{
By D.M. Imboden, B.S. F. Eid ${ }^{2}$ ), T. Joller, M. Schurter and J. Wetzel \\ Swiss Federal Institute for Water Resources and Water Pollution Control (EAWAG) \\ at Swiss Federal Institutes of Technology (ETH) \\ Manuscript received on 18 July 1979
}

\begin{abstract}
In a limno-corral (diameter $12 \mathrm{~m}$, depth to sediments $10 \mathrm{~m}$ ), located in Baldeggersee (Switzerland), vertical mixing has been measured during more than one year and compared to the conditions in the open lake (maximum depth $65 \mathrm{~m}$, surface area $5.3 \mathrm{~km}^{2}$ ). The temperature method by McEwen and Hutchinson yields $\mathrm{K}_{\mathrm{z}}$ values between $5 \times 10^{-2} \mathrm{~cm}^{2} \mathrm{~s}^{-1}$ at the upper boundary of the thermocline and $2 \times 10^{-3} \mathrm{~cm}^{2} \mathrm{~s}^{-1}$ at the bottom, a value near the molecular diffusion of heat at $4^{\circ} \mathrm{C}\left(1.36 \times 10^{-3} \mathrm{~cm}^{2} \mathrm{~s}^{-1}\right)$. $\mathrm{K}_{\mathrm{z}}$ calculated from profiles of excess radon-222 generally agree with those from the temperature data. Compared to the open lake, the corral has a more shallow epilimnion. However, during calm meteorological conditions, vertical mixing in the upper $10 \mathrm{~m}$ is similar outside and inside the corral.
\end{abstract}

\section{Introduction}

The dynamics of chemical and biological reactions in lakes is determined by the interplay of reaction kinetics and material transport mechanisms. The latter include the 'macro-processes' (advection and turbulence, particle settling) and the 'microprocesses' (molecular diffusion through boundary layers, transfer processes at cell membranes, etc.).

This article deals with the 'macro-processes', i.e. with transport mechanisms characteristic for the body of water within which chemical and biological reactions take place. Thus, it is a classical problem of hydrodynamics for which, in fact, a set of differential equations exists. Yet, since the equations are nonlinear, analytical solutions can only be found for special cases, and numerical solutions may be impossible to attain because they-strongly depend on external forces (meteorology) and boundary conditions requiring continuous or nearly continuous data collection. Under these circumstances, oceanographers and limnologists have developed simplified concepts to approximate the hydrodynamical behavior of their systems. One

1) Supported by the Swiss National Science Foundation within the framework for its National Research Program on 'Lake Currents'.

2) Present address: Department of Civil Engineering, McMaster University, Hamilton, Ont., Canada. 
approach may be used in comparing typical time rates for mixing and reaction in order to select those mixing processes which are fast relative to in-situ reactions and thus can be replaced by the concept of homogeneous mixing [1]. Another simplification is introduced by describing the complex pattern of turbulence with a few empirical parameters, the coefficients of eddy diffusion.

In fact, in most lakes and for most biological reactions horizontal mixing belongs to the class of fast processes. On the other hand, due to the strong density gradients typical for stratified lakes, vertical mixing may be much slower than in-situ reactions resulting in large vertical gradients for those chemical species involved in the reactions.

The limno-corrals in Baldeggersee (Switzerland), used for the MELIMEX experiments [2], are idealized examples of horizontally well mixed and vertically stratified lakes. However, the intensity of vertical mixing may be altered by the vertical walls separating the test lakes (corrals) from the surrounding open water. Therefore, during the whole period of the experiment, vertical mixing in one of the three containers $(C)$ was measured in order to answer the following two questions:

1. What is the influence of the walls of the corrals on the mixing structure in comparison to that of the open lake?

2. What is the absolute value of vertical eddy diffusion in the tube as a function of depth and time?

Within the error limits of the employed methods, the following discussion is representative for all the limno-corrals, since they are located close to each other in the same corner of the lake at the same depth and since in the containers mixing is primarily driven by meteorological factors (wind, solar radiation, etc.).

\section{The concept of vertical eddy diffusion}

In an open body of water turbulence leads to an irregular pattern of advection velocities, whereas molecular diffusion is too slow to play a significant role for the material transport. Due to the condition of mass conservation of fluid the arithmetic sum of all fluxes through a horizontal plane $A$ is zero provided that no subsurface inlets or outlets exist. Following the concept of Schmidt [3] (fig. 1), the net flux of dissolved material through the cross-sectional area $A$ is given by (z: depth coordinate)

$$
f_{A}=-Q_{e x} \Delta C=-Q_{e x} L \frac{\partial C}{\partial z}
$$

where $Q_{\text {ex }}=\left|Q_{\text {up }}\right|=\left|Q_{\text {down }}\right|$ is the vertical exchange of water per unit time across $A$, and $L$ is a typical vertical transport distance of the water (mixing length, in analogy to the concept of mean free path used in the theory of molecular diffusion).

The right-hand expression of eq. (1) consists of two parts, one $\left(Q_{e x} L\right)$ describing the hydrodynamic properties of the system, the other $(\partial \mathrm{C} / \partial \mathrm{z})$ depending on the 


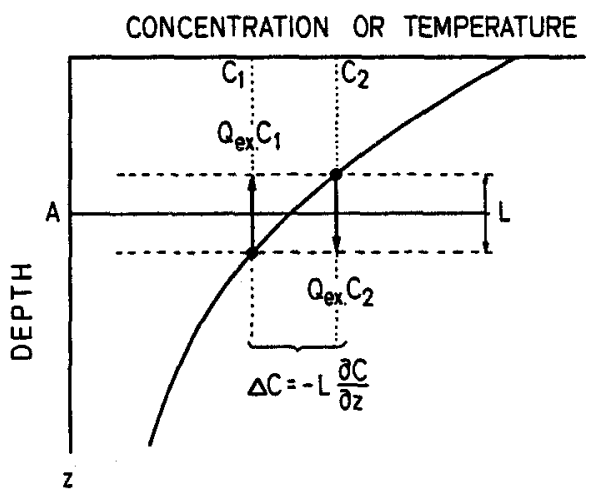

Figure 1. Schmidt's [3] concept of transport by turbulence. The vertical exchange of water per unit time $\left(Q_{e x}\right)$ across the plane $A$ causes a net material transport proportional to the concentration gradient times the mean vertical displacement $L$ (mixing length).

Abb. 1..Das Konzept von Schmidt [3] für turbulenten Transport: Die vertikale Wasseraustauschrate $Q_{\text {ex }}$ durch die Flăche $A$ bewirkt einen Nettotransport, welcher zum negativen Konzentrationsgradienten und der mittleren vertikalen Verschiebung L (Mischungslänge) proportional ist.

spatial distribution of the chemical or physical species under consideration. One defines

$$
K_{z}=\frac{Q_{e x} L}{A} \quad \text { (dimension } L^{2} T^{-1} \text { ) }
$$

as the coefficient of vertical eddy diffusion.

The flux per unit area and time, F, is given by the generalized first Fick's law:

$$
F=-K_{z} \frac{\partial C}{\partial z} .
$$

\section{The temperature method}

The temperature method to calculate coefficients of vertical eddy diffusion, $\mathrm{K}_{\mathrm{v}}$ has been introduced by McEwen [4] and later by Hutchinson [5]. It is based on the assumption that heat is transported by vertical eddy diffusion from the warm surface water into the colder hypolimnion. Thus, its application is restricted to the thermocline and hypolimnion during the stagnation period. Situations typical in autumn, when parcels of cool surface water sink into the deeper part of the lake (convective mixing), cannot be described within the above concept.

As Li [6] has pointed out, a precise absolute calibration and stability of the used thermometers is necessary to detect the extremely small temporal temperature variations during the stagnation period and to calculate the change of hypolimnic heat content. 


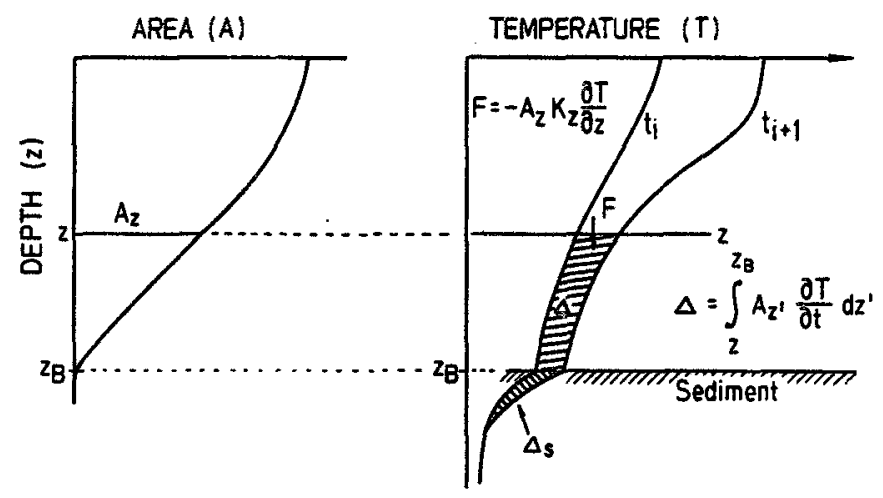

Figure 2. Calculation of vertical eddy diffusion from temperature profiles for depth depending cross-sectional area $A_{z}$ (see Jassby et al. [7]). The turbulent transport of heat across $A_{z}$ leads to an increase $\Delta$ of the heat content of the water between depth $z$ and the lake bottom $z_{B}$. In addition, the change $\Delta_{s}$ of the sediment heat content has to be considered.

Abb.2. Berechnung der vertikalen Wirbeldiffusion aus Temperaturprofilen für tiefenabhängigen Seequerschnitt $A_{2}$ (vgl. Jassby et al. [7]). Der turbulente Wärmetransport durch die Fläche $A_{z}$ erhöht den Wärmeinhalt $\Delta$ des Wassers zwischen der Tiefe $\mathrm{z}$ und dem Seegrund $\mathrm{z}_{\mathrm{B}}$. Zusătzlich muss die Veränderung des Wărmeinhaltes des Sedimentes $\Delta_{\mathrm{s}}$ berücksichtigt werden.

The equation expressing $\mathrm{K}_{\mathrm{z}}$ as a function of depth $\mathrm{z}$ and time $\mathrm{t}$ taking into account the variation of the horizontal cross-sectional area $A_{z}$ with depth is given by (fig. 2)

$$
K_{z}(z, t)=-\frac{\left.\int_{z}^{z_{B}} A_{z^{\prime}} \frac{\partial T}{\partial t}\right|_{z^{\prime}, t} d z^{\prime}}{\left.A_{z} \frac{\partial T}{\partial z}\right|_{z, t}}
$$

Eq. (4) is solved numerically with the aid of a FORTRAN program named VERDI (VERtical DIffusion). The program calculates the vertical eddy diffusion coefficient $K_{z}$ as a function of depth and time for given temperature profiles measured at consecutive times $t_{1}, t_{2}, \ldots, t_{n}$. It is very flexible with respect to the required input data. Besides lake morphology (given by a series of $A_{2}$ values) a series of temperature profiles are given at arbitrary times, and each profile consists of an arbitrary number of pairs $\left(z_{i j}, T_{j}\right)$ where the depths $z_{i}$ can be different from one profile to the next. The program yields values for $K_{2}$ at selected depths $z_{1}^{*} \cdots z_{m}^{*}$ valid for the periods between consecutive sampling times $t_{i}$ and $t_{i+1}$. It also calculates the Brunt-Väisälä (stability) frequencies ( $\rho$ : density of water; $g$ : acceleration of gravity)

$$
\mathrm{N}^{2}=\frac{\mathrm{g}}{\rho} \frac{\mathrm{d} \rho}{\mathrm{dz}} .
$$

The exponential correlation

$$
\mathrm{K}_{\mathrm{z}}=\mathrm{a}\left(\mathrm{N}^{2}\right)^{-\mathrm{b}}
$$

is often used as an empirical model for $K_{z}[7,8]$. 
With a slightly modified program, VERDIFX, the flux of heat across the sedimentwater interface can be taken into account. This leads to an additional term in the nominator of eq. (4). The heat flux in the pore water of the sediment column is described by molecular diffusion into a semi-infinite medium which stands under the influence of time-varying temperature at its upper boundary (sediment-water interface). A possible geothermal heat flux is included [9]. However, for the case of the MELIMEX containers, the influence of the thermal 'sediment memory' was found to have insignificant influence on the evaluation of $K_{z}$. The results are presented in section 5 .

\section{The radon method}

Radon-222 is the decay product of radium-226, a natural component in the sediment. Radon diffuses from the place of its origin to the overlying lake water where it is transported upwards by turbulence. Its half-life is 3.8 days.

Broecker [10] has first used vertical radon profiles in the deep sea to calculate eddy diffusion. The same method can be applied to lakes [11], though complications may arise due to the relatively narrow bottom topography of lakes compared to the vast abyssal planes of the deep ocean. Furthermore, horizontal currents may make it necessary to use three-dimensional diffusion/advection models to account for all the structure found in lacustrine near-bottom radon profiles.

Since horizontal advection is suppressed, the MELIMEX limno-corrals represent ideal systems to apply the one-dimensional radon diffusion model [11]

$$
\mathbf{R}(\zeta)=\mathbf{R}_{0} \exp \left(-\sqrt{\frac{\lambda}{\mathbf{K}_{\mathrm{z}}}} \zeta\right)
$$

$\mathbf{R}_{0}, \mathbf{R}(\zeta)$ : Excess radon activity at the sediment-water interface and at distance $\zeta$ from the sediments; $R=$ (activity of $\left.{ }^{222} R n\right)-\left(\right.$ activity of $\left.{ }^{226} R a\right)$.

$\lambda$ : Decay constant of ${ }^{222} \mathrm{Rn}\left(0.00755 \mathrm{~h}^{-1}\right)$.

For constant $\mathrm{K}_{z}$, a plot of $\ln \mathrm{R}$ versus $\zeta$ should yield a straight line with the slope $-\sqrt{\lambda / K_{z}}$. However, it was found from the temperature method that in the MELIMEX corrals $\mathrm{K}_{\mathrm{z}}$ is so extremely small that $\mathrm{R}$ drops to $10 \%$ of its boundary value $R_{0}$ within $1-2 \mathrm{~m}$. (For instance, with $K_{z}=4 \times 10^{-3} \mathrm{~cm}^{2} \mathrm{~s}^{-1}$, the exponent $\sqrt{\lambda / \mathrm{K}_{\mathrm{z}}}$ is $2.3 \mathrm{~m}^{-1}$.) Thus, the radon is confined to the lowest layer of the corral.

\section{Results and discussion}

Temperature profiles were taken every second week inside and outside the corral $\mathrm{C}$ and at a mid-lake station where the lake reaches its maximum depth of $65 \mathrm{~m}$. A temperature/pressure sonde was used with a resolution of $2 \times 10^{-3}{ }^{\circ} \mathrm{C}$ and an accuracy of more than $10^{-2}{ }^{\circ} \mathrm{C}$. In the second year, the station outside $\mathrm{C}$ was abandoned. In figure 3 the isothermals in the corral are compared with those of the upper $10 \mathrm{~m}$ at the mid-lake station. Some systematic differences can be seen, especially in the shape and depth of the thermocline, further examplified by the 

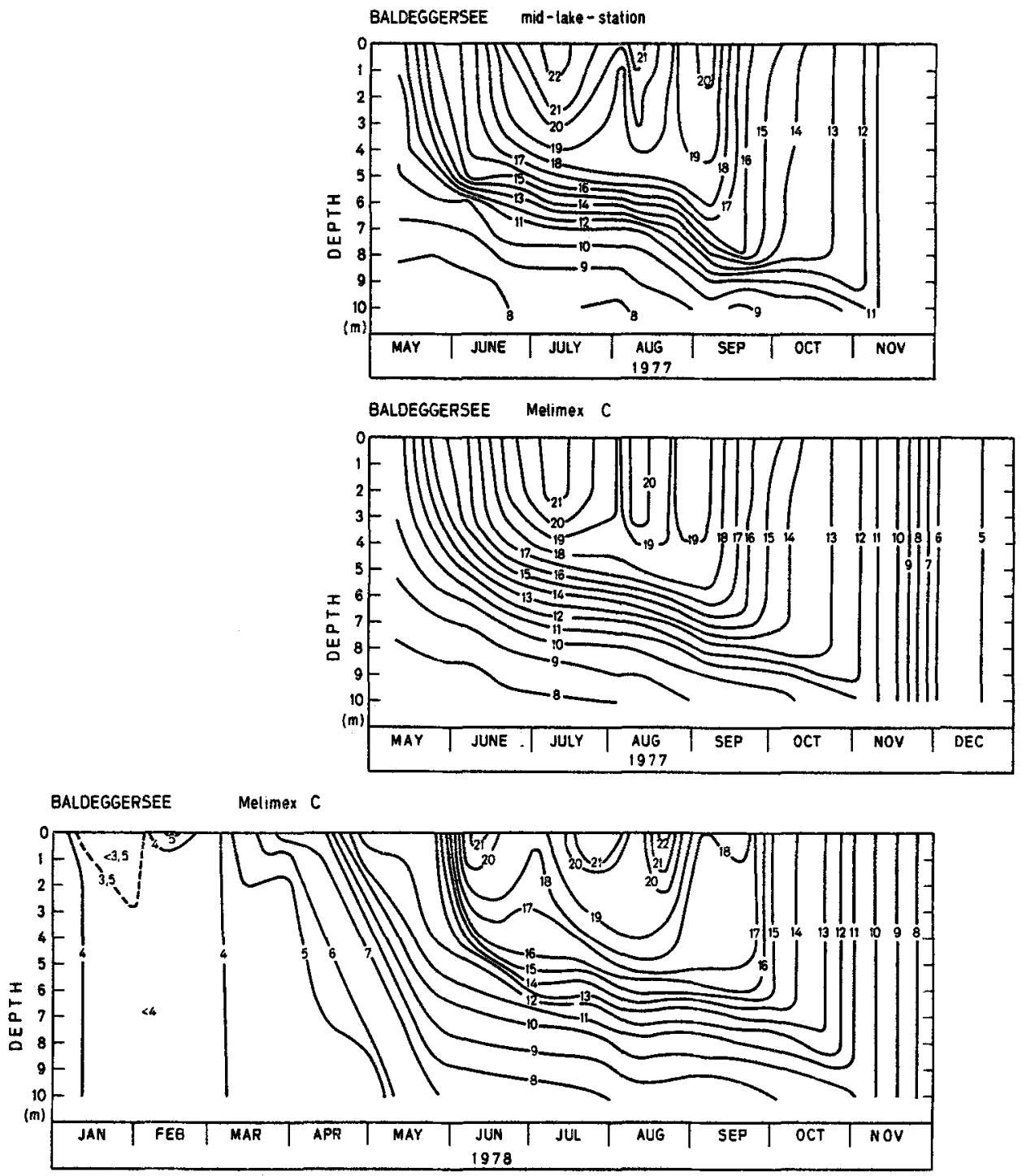

Figure 3. Isothermal lines of Baldeggersee.

Abb.3. Isothermen des Baldeggersees.

selected profiles in figure 4. Generally, the open lake has a deeper epilimnion than the container (fig. 5), since the wind force is more efficient on the open surface. A further discussion of the fine-structure in the profiles would lie beyond the aim of this article. However, we would like to stress the fact that some of the differences between the mid-lake station and that one outside $\mathrm{C}$ are artefacts due to the different day time of the measurements (see the top $2 \mathrm{~m}$ on 11 May 1977) and due to internal waves at the thermocline which have their largest amplitudes 

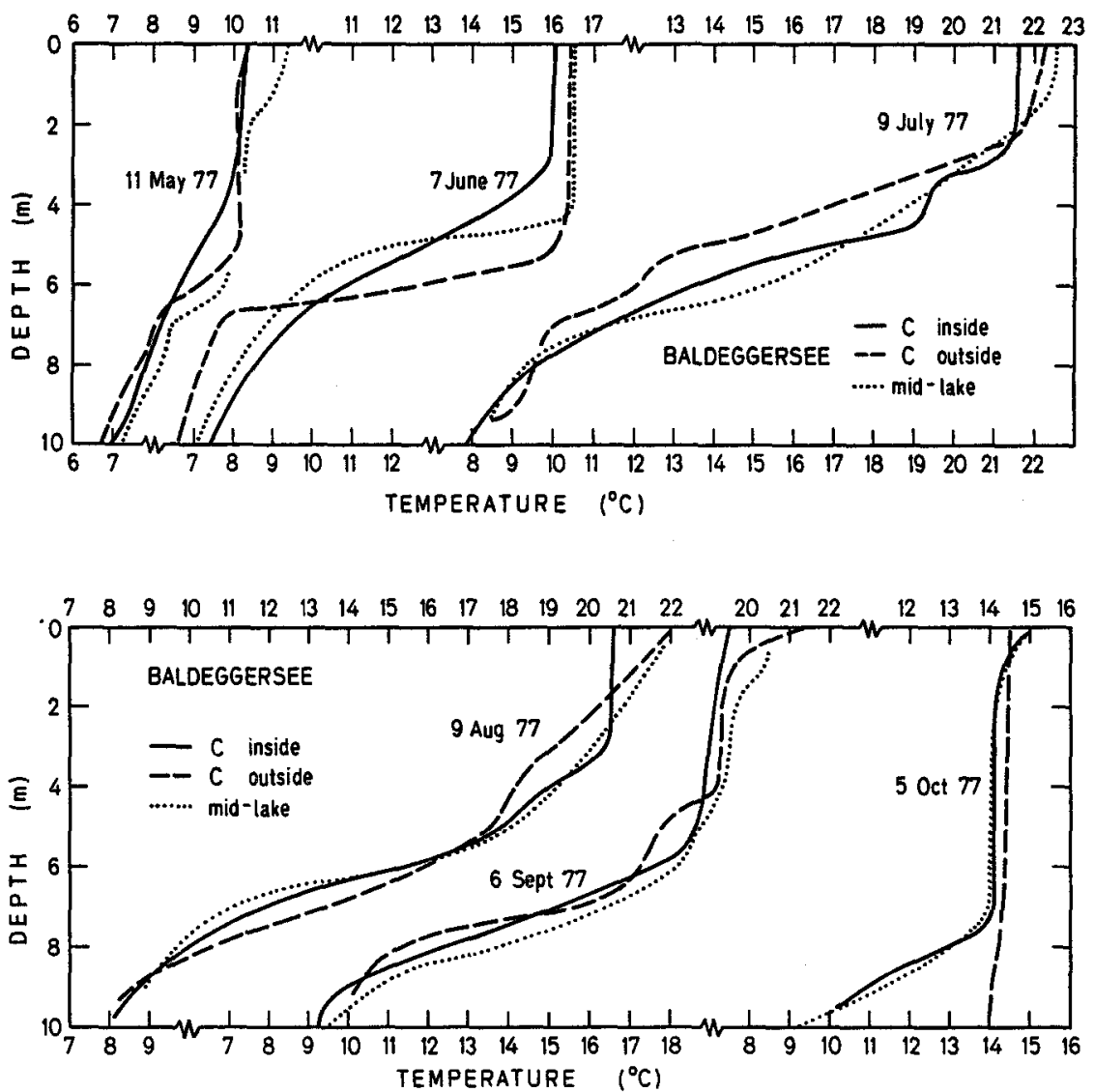

Figure 4. Comparison of selected temperature profiles inside and outside the MELIMEX limno-corral $\mathrm{C}$ in Baldeggersee during 1977.

Abb.4. Vergleich ausgewählter Temperaturprofile innerhalb und ausserhalb des MELIMEX-Modellsees C.

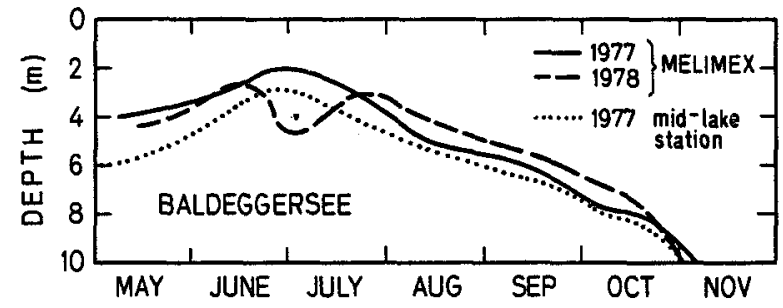

Figure 5. Depth of epilimnion in Baldeggersee. Abb.5. Tiefe des Epilimnions im Baldeggersee. 
at the end of the elongated lake basin, that is at the MELIMEX containers (see 7 June 1977 observations).

From figure 3 it appears that between June and September the temperature regime in $\mathrm{C}$ below the epilimnion is fairly smooth and stable, a prerequisite to apply the temperature method (see section 3 ). The vertical mixing, made visible by the warming of the hypolimnion, seems to be quite constant during this period.

We have used the program VERDI to calculate $K_{z}$ from the temperature profiles of the limno-corral (fig. 6). From May to the end of June, $\mathrm{K}_{\mathrm{z}}$ is increasing with time and strongly depth-dependent. Near the bottom it reaches a value only slightly above the coefficient of molecular diffusion of heat at $4^{\circ} \mathrm{C}\left(1.36 \times 10^{-3} \mathrm{~cm}^{2} \mathrm{~s}^{-1}\right)$. Between 21 June and 3 August, $\mathrm{K}_{\mathrm{z}}$ is relatively constant in the lowest $4 \mathrm{~m}$ of the container and near its molecular value. Probably as a result of a meteorological perturbation, $\mathrm{K}_{\mathbf{z}}$ is again larger in mid-August and reaches another minimum in September. Due to the drop of the thermocline (fig. 5 ) accompanied by convective turbulence, the eddy diffusion concept loses its validity in September.

Above the thermocline, vertical mixing is extremely time-dependent. A series of warm and quiet days occasionally permits the evolution of a temperature gradient up to the water surface, but such a structure is only of transient character, since the slightest wind input may destroy it. The biweekly temperature profiles do not allow to describe the temporal fine-structure of the near-surface vertical mixing.

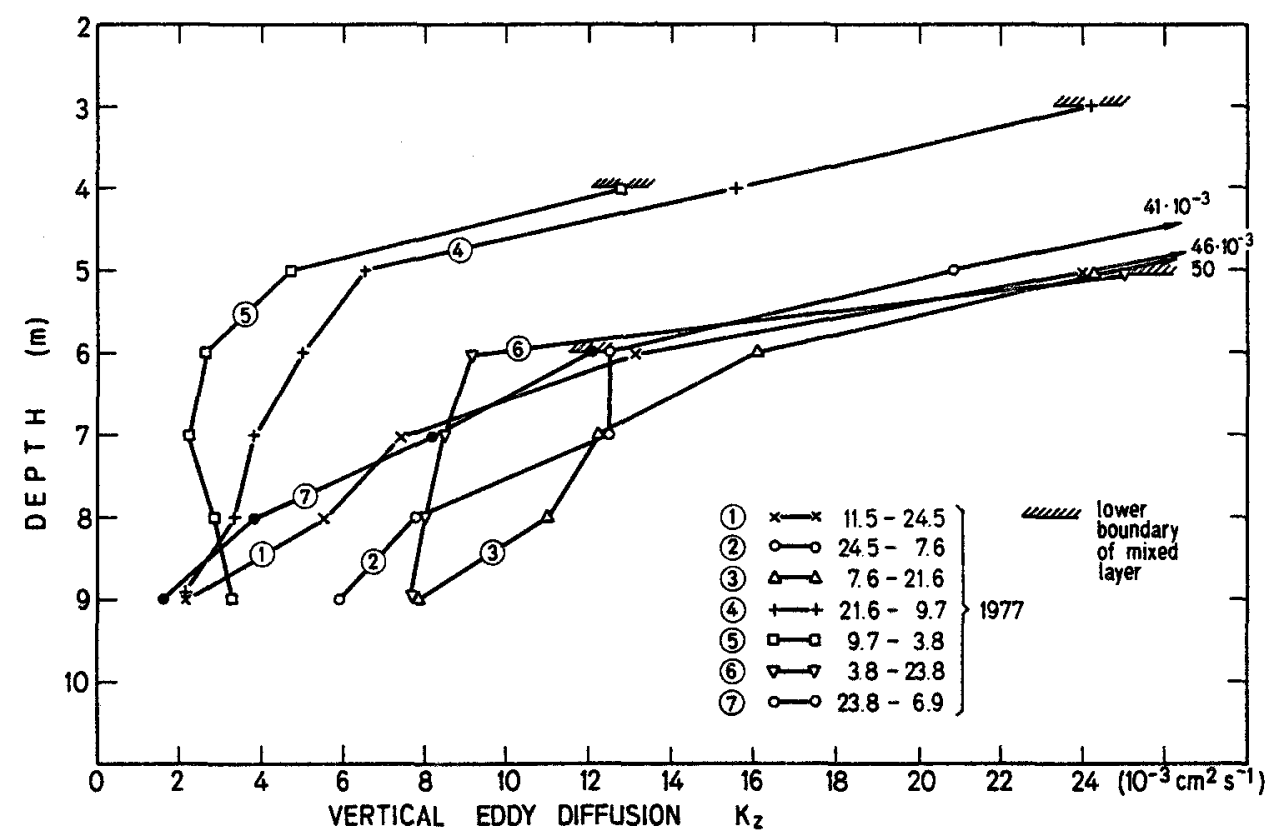

Figure 6. Coefficient of vertical eddy diffusion $\mathrm{K}_{\mathbf{z}}$ inside the MELIMEX limno-corral C, calculated with the temperature method, eq. (4).

Abb.6. Vertikaler Wirbeldiffusionskoeffizient $\mathrm{K}_{\mathrm{z}}$ im MELIMEX-Modellsee $\mathrm{C}$, mit der Temperaturmethode, Gl. (4), berechnet. 


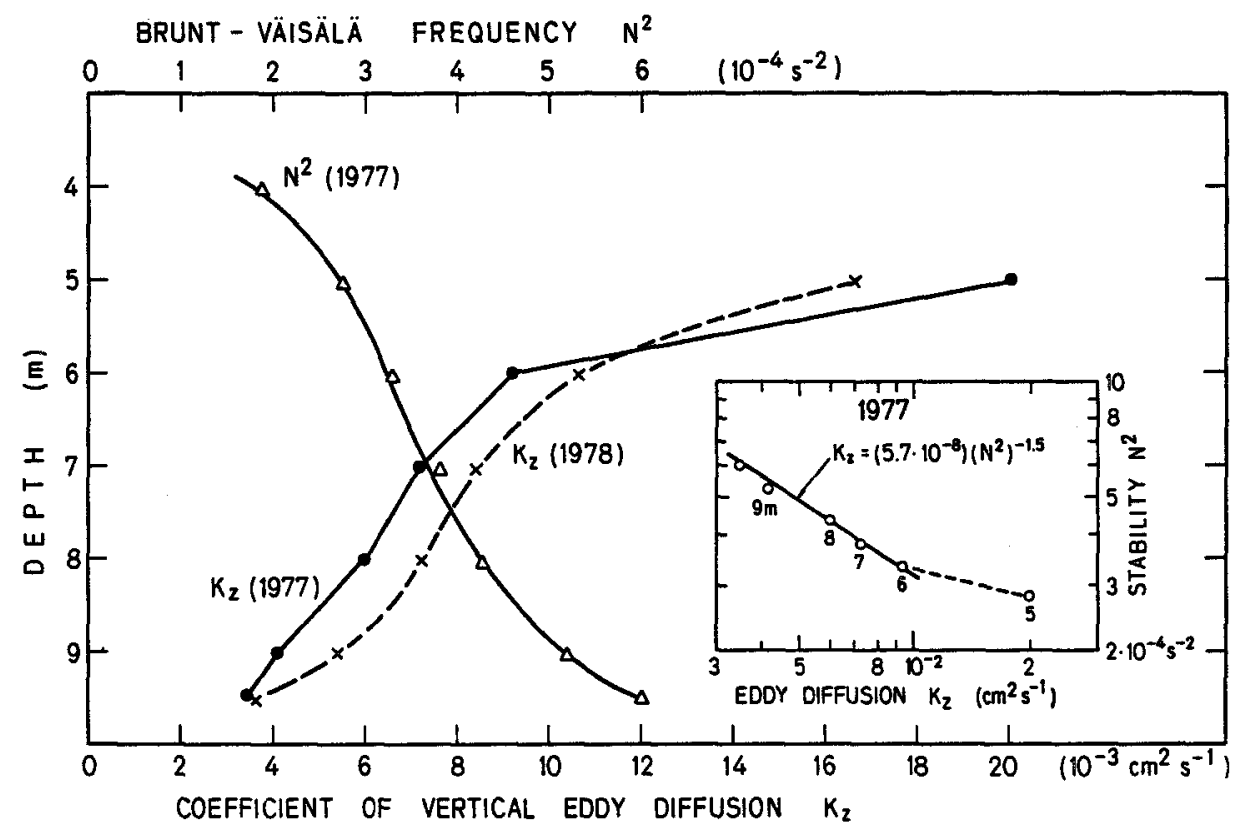

Figure 7. Vertical eddy diffusion $\mathrm{K}_{\mathrm{z}}$ in limno-corral $\mathrm{C}$, averaged for constant depth over the stagnation periods of the years 1977 and 1978. The Brunt-Väisala frequency $N^{2}$ for 1977 is averaged correspondingly and correlated with $\mathrm{K}_{\mathrm{z}}$ (see insert). For real lakes exponents b, eq. (6), are usually smaller than 1.

Abb.7. Mittleres Profil des vertikalen Wirbeldiffusionskoeffizienten $\mathbf{K}_{\mathbf{z}}$ wăhrend der Stagnationsperioden 1977 und 1978. Die gemittelte Brunt-Väisälä-Frequenz $\mathrm{N}^{2}$ für das Jahr 1977 ist mit $\mathrm{K}_{\mathbf{z}}$ korreliert (vgl. Einschub). Für natürliche Seen ist der Exponent b, Gl. (6), meist kleiner als 1.

However, the 'total mixing events' are frequent enough compared with the relevant chemical and biological reaction rates. Thus, the epilimnion can be treated as a permanently completely mixed system.

In 1978, the average vertical mixing was similar (fig. 7). Of course, the details of the mixing structure reflect the different meteorological conditions in the 2 years (see fig. 3).

A possible error may be introduced into the one-dimensional temperature model by horizontal heat exchange across the walls of the corral. If the temperature at a given depth is higher inside the corral, it would lose heat through the walls leading to an underestimation of $K_{z}$ calculated using the program VERDI. The situation may be most critical in June and July when temperature differences across the wall of more than $1^{\circ} \dot{\mathrm{C}}$ exist. Nevertheless, we estimate the horizontal heat flux to be not larger than $30 \%$ of the vertical flux. In fact, the double layer structure of the walls reduces the horizontal heat flux (see Gächter [2] for details of the wall structure). Also, due to internal waves the average horizontal temperature differences between lake and container are probably better represented by the mid-lake station, and those profiles are more similar to the conditions in the corral than the 'snapshot' profiles of the oscillating conditions outside the corral. 


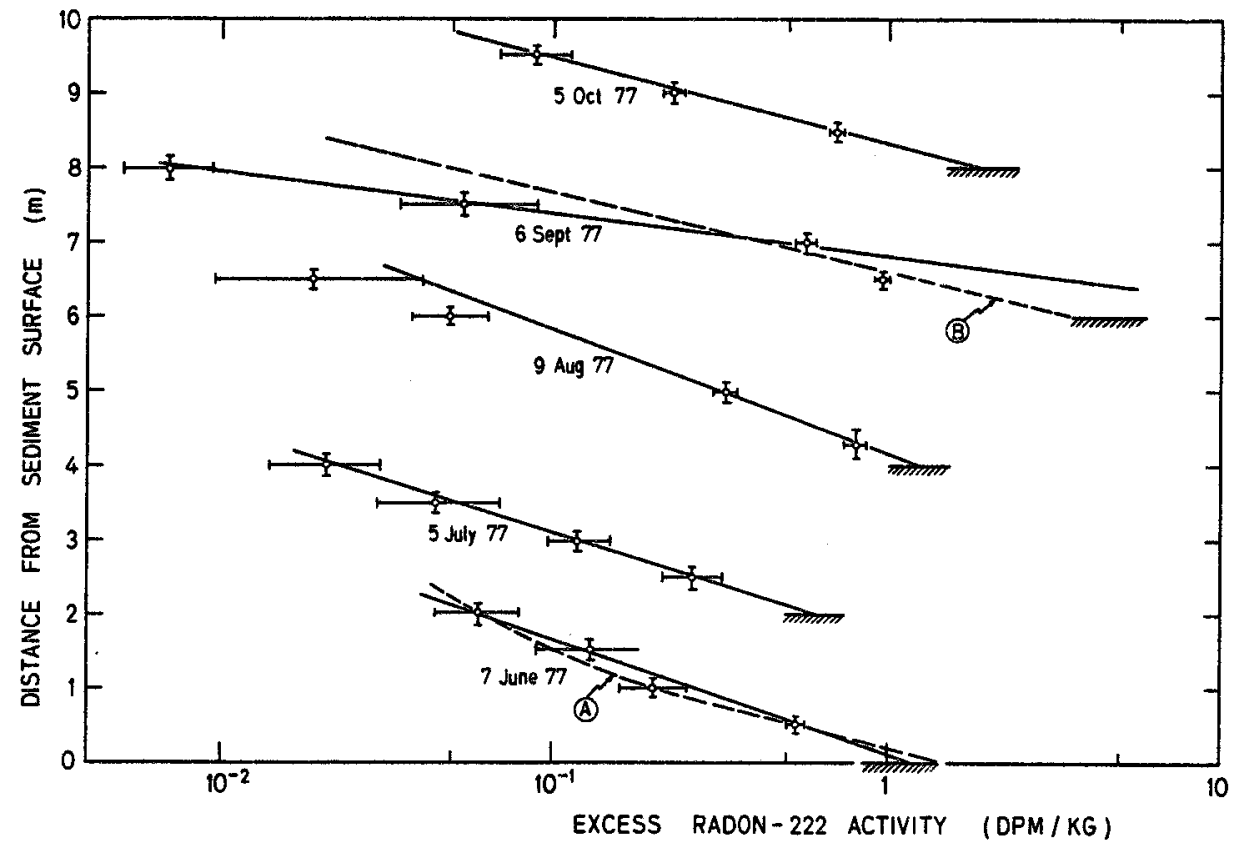

Figure 8. Profiles of excess radon from the MELIMEX corral C. Error bars correspond to one standard deviation.

Abb.8. Profile für Überschuss-Radon im MELIMEX-Modellsee C. Die Fehlerbalken entsprechen einer Standardabweichung.

It is, however, possible that the extremely small $\mathrm{K}_{\mathrm{z}}$ values in June and July are underestimated by up to $30 \%$, a presumption supported by the radon measurements plotted in figure 8.

Values of $K_{z}$ were calculated from the radon profiles using eq. (7). The depth dependence of $\mathrm{K}_{\mathrm{z}}$ found from the temperature method should change the linear relation between $\zeta$ and $\ln \mathrm{R}(\zeta)$ into a curve which is convex downwards. This could however not be seen from the data, probably since the measurable excess radon was confined to a layer hardly ever more than $2 \mathrm{~m}$ thick. The profile from 7 June 1977 may be an exception (see curve A in fig. 8).

The interpretation of the profile from 6 September 1977 creates some problems: either $\mathrm{K}_{2}$ is larger in the deepest part of the corral (which is unlikely regarding the temperature date), or one of the measurements is wrong. Curve B (fig. 8) is the weighted linear regression using all data; we believe, however, that the fully drawn curve, for which the lowest data was omitted, deserves higher credibility.

The two independent methods to calculate $K_{z}$ yield consisting results (fig.9), despite of the fact that different temporal and spatial averages are implicitly taken in the two cases (table). The only significant discrepancy (5 July 1977) has to be considered under this aspect. The low average mixing between 21 June and 9 July may not have been representative of the few days preceeding the date of radon sampling ( 5 July). Also as mentioned before, due to horizontal heat flux the temperature method may yield too low values for $\mathrm{K}_{\mathrm{z}}$ during this period. 


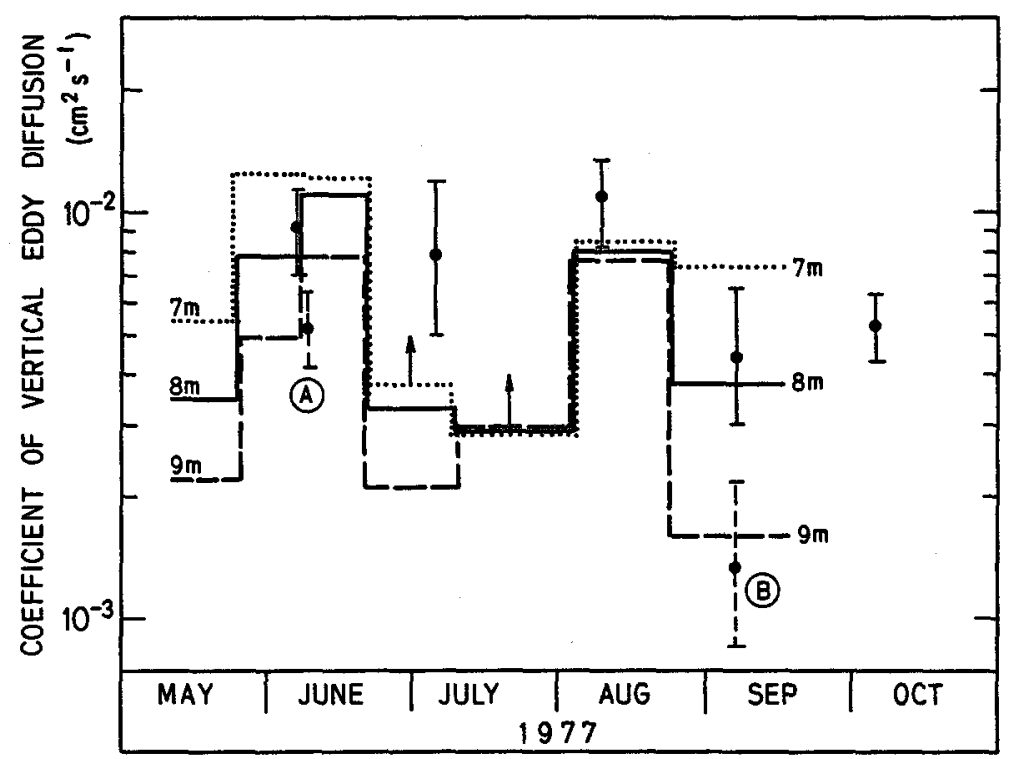

Figure 9. Comparison of $\mathrm{K}_{\mathrm{z}}$ values in MELIMEX corral $\mathrm{C}$, calculated by the temperature method (step curve) and by the radon method (points with $1 \sigma$ error bars). See text for the meaning of $A$ and B. Arrows indicate time periods where horizontal heat conduction across the corral walls may lead to underestimated $\mathrm{K}_{\mathbf{z}}$ values.

Abb.9. Vergleich von $\mathrm{K}_{\mathbf{z}}$ im MELIMEX-Modellsee $\mathrm{C}$, berechnet einerseits mit der Temperaturmethode (Treppenkurve) und anderseits aus Radon-Messungen (Punkte mit Fehlerbalken). Bedeutung von $A$ und B vgl. Text. Pfeile bezeichnen Perioden, während deren der horizontale Wärmetransport durch die Wände des Modellsees zu einer Unterschätzung des berechneten $\mathrm{K}_{\mathbf{2}}$ führen $k a n n$.

Averaging properties of two methods for the calculation of vertical eddy diffusion coefficients.

\begin{tabular}{lll}
\hline $\begin{array}{l}\text { Temperature } \\
\text { method }\end{array}$ & With respect to time & With respect to space \\
\hline $\begin{array}{l}\text { Arithmetic mean over period } \\
\text { between two consecutive } \\
\text { temperature profiles }\end{array}$ & $\begin{array}{l}\text { Spatial resolution as good } \\
\text { as spacing of temperature } \\
\text { data within the vertical } \\
\text { profile }\end{array}$ \\
\hline Radon method & $\begin{array}{l}\text { Steady-state model; constant } \\
\text { conditions required for about } \\
2 \text { half-lives of } R n(\sim 7 \text { days })\end{array}$ & $\begin{array}{l}\text { Weighted vertical mean within } \\
\text { layers with measurable excess } \\
\text { radon activity* }\end{array}$ \\
\hline
\end{tabular}

* Weighting of mean depends on the used regression method between depth and In R. Usually, we weight the data in proportion to their value of excess radon, i.e. the points nearest to the sediment surface receive the largest weight.

We come back to the first question posed in section 1: How is the vertical mixing regime in the corral altered relative to that in the open lake? Comparing the isotherms of figure 3 one intuitively feels that, beside the different position of the thermocline, the average downward flux of heat is roughly the same in both systems. Indeed, during quiet conditions, $\mathrm{K}_{\mathrm{z}}$ can be calculated in the open lake from the bottom up to the lower boundary of the epilimnion using the program VERDI. 
The values are similar as those in the corrals. However, the main difference lies in the sensibility of the temperature structure in the two systems with respect to meteorological forces: The open lake is more sensitive to kinetic energy input (wind). In fact, a heavy storm may disturb the temperature structure down to a depth of over $10 \mathrm{~m}$, whereas the same event in the corral leaves the layers below $5 \mathrm{~m}$ practically unaffected. It is not surprising that the average $\mathrm{K}_{\mathrm{z}}$ drops faster with stability $\mathrm{N}^{2}$ [see eq. (6)] than under open lake conditions (fig. 7).

On the other hand, the corrals are more sensitive with respect to heat exchange at the surface due to their smaller depth. For instance, in February 1978, the corrals were ice-covered during several weeks whereas a thin ice layer covered part of the open lake only during a few days.

In conclusion, the mixing regime in the limno-corrals differs from that in the lake in a similar way as a small pond is different from a lake. However, the stabilizing effect on the corrals is much smaller than expected for a real (isolated) lake with the same surface-to-depth ratio. This is probably due to the transfer of mechanical energy from the open lake through the flexible wall of the corral into the artificial lake. On the other hand, the mixing effect of the pulsating walls is less important than originally supposed and far too weak to destroy the stratification.

\section{Summary}

In a limno-corral (diameter $12 \mathrm{~m}$, depth to sediments $10 \mathrm{~m}$ ), located in Baldeggersee (Switzerland), vertical mixing has been measured during more than one year and compared to the conditions in the open lake (maximum depth $65 \mathrm{~m}$, surface area $5.3 \mathrm{~km}^{2}$ ). The temperature method by McEwen and Hutchinson yields $K_{z}$ values between $5 \times 10^{-2} \mathrm{~cm}^{2} \mathrm{~s}^{-1}$ at the upper boundary of the thermocline and $2 \times 10^{-3} \mathrm{~cm}^{2} \mathrm{~s}^{-1}$ at the bottom, a value near the molecular diffusion of heat at $4^{\circ} \mathrm{C}(1.36$ $\times 10^{-3} \mathrm{~cm}^{2} \mathrm{~s}^{-1}$ ). During the period of largest heating (June, July) horizontal heat conduction across the walls of the container may lead to an underestimation of $\mathrm{K}_{\mathrm{z}}$ of maximal $30 \% . \mathrm{K}_{\mathrm{z}}$ calculated from profiles of excess radon-222 generally agree with those from the temperature data. Compared to the open lake, the corral has a more shallow epilimnion. Turbulent energy input from wind does not significantly affect the temperature structure below $5 \mathrm{~m}$, whereas at a mid-lake station turbulence penetrates to more than $10 \mathrm{~m}$. During calm conditions, vertical mixing in the upper $10 \mathrm{~m}$ is similar outside and inside the corral.

\section{ZUSAMMENFASSUNG}

Im Rahmen des MELIMEX-Programms [2] wurde in einem der verwendeten Modellseen (Zylinder, durch schwimmende und im Sediment verankerte Wände abgetrennt, Durchmesser $12 \mathrm{~m}$, Tiefe $10 \mathrm{~m}$ ) die Intensităt der vertikalen Durchmischung gemessen und mit derjenigen im umgebenden Wasser des Baldeggersees verglichen. Nach Schmidt [3] kann der vertikale Austausch durch einen Wirbeldiffusionskoeffizienten $K_{2}$ beschrieben werden (Abb. 1). Die Temperaturmethode von McEwen [4] (Abb.2) ergibt $\mathrm{K}_{\mathrm{z}}$-Werte zwischen $5 \times 10^{-2} \mathrm{~cm}^{2} \mathrm{~s}^{-1}$ unterhalb der Sprungschicht und $2 \times 10^{-3} \mathrm{~cm}^{-2} \mathrm{~s}^{-1}$ am Grund (Abb.6), ein Wert, der nur wenig oberhalb des Wärmediffusionskoeffizienten bei $4^{\circ} \mathrm{C}(1.36$ $\times 10^{-3} \mathrm{~cm}^{2} \mathrm{~s}^{-1}$ ) liegt. Während der Zeit grösster Erwärmung des Sees (Juni, Juli) kann die horizontale Wärmeleitung durch die Wände des Modellsees zur Folge haben, dass $\mathbf{K}_{\mathbf{2}}$ um maximal $30 \%$ unterschătzt wird. Korrelationen zwischen $K_{z}$ und der Brunt-Văisălä-Frequenz $N^{2}$ (ein Mass für die 
Stärke der vertikalen Dichteschichtung) zeigen, dass innerhalb des Modellsees $\mathbf{K}_{\mathbf{z}}$ schneller abnimmt mit zunehmender Frequenz (Stabilităt) $\mathrm{N}^{2}$ als in offenen Gewässern (Abb.7).

Die Berechnung von $\mathrm{K}_{\mathrm{z}}$ aus vertikalen Profilen des aus dem Sediment austretenden natürlichen, radioaktiven Isotops Radon-222 (Abb.8) ergibt ein mit der Temperaturmethode übereinstimmendes Resultat (Abb.9), obschon die beiden Methoden implizit unterschiedlichen Arten der zeitlichen und örtlichen Mittelwertbildung entsprechen (Tabelle).

Im Vergleich zum offenen See entwickeln sich sehr ăhnliche Temperaturstrukturen innerhalb und ausserhalb des Modellsees (Abb.3, 4), doch wird innen der Einfluss meteorologischer Störungen vertikal viel stărker gedämpft als in offenen See. Im allgemeinen liegt daher auch die Sprungschicht im offenen See etwas tiefer (Abb.5). Umgekehrt erwies sich eine anfangliche Befürchtung, der turbulente Energieübertrag vom See auf das Innere des Wasserzylinders könnte zu einer vollständigen vertikalen Durchmischung des Systems führen (Pumpeffekt), als unrichtig.

\section{RÉSUME}

Dans un modèle de lac (cylindre de $12 \mathrm{~m}$ de diamètre, $10 \mathrm{~m}$ de haut, posé sur le fond), installé dans le lac de Baldegg (Suisse), le mélange vertical a été mesuré pendant plus d'un an et a été comparé aux conditions existantes dans le lac naturel (profondeur maximale $65 \mathrm{~m}$, surface $5,3 \mathrm{~km}^{2}$ ). La méthode de McEwen et Hutchinson, basée sur la température, prouve que les valeurs $K_{z}$ sont entre $5 \times 10^{-2}$ $\mathrm{cm}^{2} \mathrm{~s}^{-1}$ à la limite supérieure du thermocline et $2 \times 10^{-3} \mathrm{~cm}^{2} \mathrm{~s}^{-1}$ en dessous, une valeur près de la diffusion moléculaire thermique à $4^{\circ} \mathrm{C}\left(1,36 \times 10^{-3} \mathrm{~cm}^{2} \mathrm{~s}^{-1}\right)$. Pendant la période d'échauffement la plus intense (juin, juillet) la conduite thermique horizontale à travers la paroi du cylindre peut amener à une sous-estimation de $\mathrm{K}_{\mathbf{z}}$ de $30 \%$ au maximum. Les valeurs $\mathrm{K}_{\mathbf{z}}$ calculées à partir des profiles de surplus de radon-222 s'accordent normalement avec celles calculées à partir de la température. Comparé avec le lac, le modèle à un épilimnion plus bas. L'introduction de l'énergie turbulante du vent n'affecte pas considérablement la structure de température en dessous de $5 \mathrm{~m}$, tandis que la turbulance au milieu du lac pénètre à plus de $10 \mathrm{~m}$ de profondeur. Par temps calme, le mélange vertical dans les $10 \mathrm{~m}$ supérieurs est le même dans le modèle que dans le lac.

\section{REFERENCES}

1 Imboden, D.M., and Lerman, A.: Chemical models of lakes. In: Lerman, A. (ed.): Lakes: Chemistry, Geology, Physics. Springer, New York 1978.

2 Gächter, R.: MELIMEX, an experimental heavy metal pollution study: Goals, experimental design and major findings. Schweiz. Z. Hydrol. 41, 169-176 (1979).

3 Schmidt, W.: Wirkungen der ungeordneten Bewegungen im Wasser der Meere und Seen. Ann. Hydrogr. marit. Meteorol. 45, 367, 431 (1917).

4 McEwen, G.F.: A mathematical theory of the vertical distribution of temperature and salinity in water under the action of radiation, conduction, evaporation, and mixing due to the resultant convection. Bull. Scripps Inst. Oceanogr. 2, 197 (1929).

5 Hutchinson, G.E.: A treatise in Limnology, vol.1. Wiley, New York 1957.

6 Li, Y.-H.: Vertical eddy diffusion coefficient in Lake Zürich. Schweiz. Z. Hydrol. 35, 1 (1973).

7 Jassby, A., and Powell, T.: Vertical patterns of eddy diffusion during stratification in Castle Lake, California. Limnol. Oceanogr. 20, 530 (1975).

8 Welander, P.: Theoretical forms for the vertical exchange coefficients in a stratified fluid with application to lakes and seas. Geophys: Gothob. 1, 1 (1968).

9 Von Herzen, R.P., Finckh, P., and Hsï, K.J.: Heat-flow measurements in Swiss lakes. J. Geophys. 40, 141 (1974).

10 Broecker, W.S.: An application of natural radon to problems in ocean circulation. In: Ichiye, T. (ed.): Diffusion in oceans and fresh waters, p.116-145. Lamont Geol. Observatory (1965).

11 Imboden, D.M., and Emerson, S.: Natural radon and phosphorus as limnologic tracers: Horizontal and vertical eddy diffusion in Greifensee. Limnol. Oceanogr. 23, 77 (1978).

Address of the authors: EAWAG, Uberlandstrasse 133, CH-8600 Dübendorf, Switzerland. 